\title{
Not so sluggish: the success of the Felimare picta complex (Gastropoda, Nudibranchia) crossing Atlantic biogeographic barriers
}

Frederico Almada, André Levy, Joana I Robalo

The molecular phylogeny of the Atlanto-Mediterranean species of the genus Felimare, particularly those attributed to the species $F$. picta, was inferred using two mitochondrial markers (16S and COI). A recent revision of the Chromodorididae clarified the taxonomic relationships at the family level reclassifying all eastern Pacific, Atlantic and Mediterranean species of the genus Hypselodoris and two species of the genus Mexichromis, within the genus Felimare. However, conflicting taxonomic classifications have been proposed for a group with overlapping morphological characteristics and geographical distributions designated here as the Felimare picta complex. Three major groups were identified: one Mediterranean and amphi-Atlantic group; a western Atlantic group and a tropical eastern Atlantic group. F. picta forms a paraphyletic group since some subspecies are more closely related with taxa traditionaly classified as independent species (e.g. F. zebra) than with other subspecies with allopatric distributions (e.g. F. picta picta and F. picta tema). Usually, nudibranchs have adhesive demersal eggs, short planktonic larval phases and low mobility as adults unless rafting on floating materials occurs. However, the phylogeny of the $F$. picta complex suggests they had an unusual success crossing main Atlantic biogeographic barriers including the mid-Atlantic barrier. This ability to cross different biogeographic barriers may be related with F. picta distinct life history and ecological traits. Compared to other Chromodorididae F. picta presents large eggs and planktotrophic larvae which could be related with a longer planktonic phase. 
1 Not so sluggish: the success of the Felimare picta complex (Gastropoda, Nudibranchia)

2 crossing Atlantic biogeographic barriers

3

4

5 Frederico Almada ${ }^{1}$; André Levy ${ }^{1}$; Joana Isabel Robalo ${ }^{1}$

6

$7 \quad{ }^{1}$ MARE - Marine and Environmental Sciences Centre, ISPA Instituto Universitário de Ciências 8 Psicológicas, Sociais e da Vida, Lisbon, Portugal

10 Corresponding author:

11 Frederico Almada; ISPA Instituto Universitário, Rua Jardim do Tabaco 34, 1149-041, Lisbon, 12 Portugal

13 Email address: falmada@ispa.pt. 


\section{Abstract}

The molecular phylogeny of the Atlanto-Mediterranean species of the genus Felimare, particularly those attributed to the species F. picta, was inferred using two mitochondrial markers (16S and COI). A recent revision of the Chromodorididae clarified the taxonomic relationships at the family level redefiningthe genus Felimare. However, conflicting taxonomic classifications have been proposed for a restrict group of taxa with overlapping morphological characteristics and geographical distributions designated here as the Felimare picta complex. Three major groups were identified: one Mediterranean and amphi-Atlantic group; a western Atlantic group and a tropical eastern Atlantic group. F. picta forms a paraphyletic group since some subspecies are more closely related with taxa traditionaly classified as independent species (e.g. F. zebra) than with other subspecies with allopatric distributions (e.g. F. picta picta and $F$. picta tema). Usually, nudibranchs have adhesive demersal eggs, short planktonic larval phases and low mobility as adults unless rafting on floating materials occurs. Surprisingly however, the phylogeny of the $F$. picta complex suggests that they successfully cross main Atlantic biogeographic barriers including the mid-Atlantic barrier. This ability to cross different biogeographic barriers may be related to $F$. picta's distinct life history and ecological traits. Compared to other Chromodorididae $F$. picta has larger eggs and planktotrophic larvae which could be related to a longer planktonic phase.

Keywords: mitochondrial DNA, mid-Atlantic barrier, speciation

\section{Introduction}

Nudibranchs are heterobranch mollusks (Gastropoda) that comprise more than 3000 species

(Willan \& Coleman, 1984). The family Chromodorididae includes some of the most striking colored nudibranchs present in almost all marine habitats. Conspicuous aposematic colorations advertise defensive adaptations that include the production or incorporation of bioactive chemicals from cnidarians or sponges upon which they feed (Wollscheid \& Wägele, 1999; Haber et al., 2010). These toxins have captured the interest of numerous authors (Gaspar, Rodrigues \& Calado, 2009; Haber et al., 2010; Cruz, Gaspar \& Calado, 2012) and represent a source of 
chromodorids are also good models for the study of color pattern evolution and mimicry in marine species (Gosliner \& Johnson 1999).Clarifying the evolutionary relationships among chromodorids would pave the way to predict characteristics that are still undescribed and would help to disentangle genetic from environmental effects (e.g. Gaspar, Rodrigues \& Calado, 2009). The taxonomy of the chromodorid nudibranchs was originally based on morphological data (Rudman, 1984). Gosliner \& Johnson (1999) revised the phylogeny of the worldwide genus Hypselodoris, including some of the species that are more abundant in the northeastern Atlantic and Mediterranean Sea. These revisions were followed by a number of morphological (Alejandrino \& Valdés, 2006) and molecular studies (Wollscheid \& Wägele, 1999; WollscheidLengeling et al., 2001; Turner \& Wilson, 2007; Johnson, 2011), including the description of several new species (Dacosta, Padula \& Schrödl, 2010; Ortigosa \& Valdés, 2012). Johnson \& Gosliner (2012), based on two mitochondrial genes, proposed a new phylogenetic hypothesis of the chromodorid and reorganized its traditional taxonomy. These authors identified the Pacific Ocean as an effective biogeographic barrier, proposing the inclusion of all eastern Pacific, Atlantic and Mediterranean Hypselodoris, together with two species from the genus Mexichromis from the eastern Pacific and Caribbean, into a different genus, Felimare, while retaining the west/central Pacific Hypselodoris species within this genus. Eastern Pacific, Atlantic and Mediterranean species previously in the genera Chromodoris and Glossodoris were included within the Felimida. Prior to their revision, Hypselodoris, Chromodoris and Glossodoris were the most species rich chromodorid genera. Recently, using additional species of these genera and a nuclear DNA marker, Ortigosa et al. (2014) recovered a polytomy between several Atlantic and Mediterranean Felimida and Felimare species.

\subsection{Taxonomic considerations of Felimare picta}

Within the Chromodorididae $F$. picta presents the wider distribution area throughout the tropical and subtropical Atlantic Ocean, including the Mediterranean Sea and the eastern Atlantic archipelagos of Cape Verde, Canaries, Madeira and Azores (Ortea, Valdés \& García-Gómez, 1996). These coastal sea slugs are one of the largest chromodorid species and vary greatly in colour and pattern, resulting in the traditional classification under many species names (e.g. Felimare (Hypselodoris) webbi (d'Orbigny, 1839) and Felimare (Hypselodoris) tema (Edmunds, 1981)). Variation in external morphology or internal anatomy also led to incongruencies in the 
80 taxonomic classification of $F$. picta subspecies (Ortea, Valdés \& García-Gómez, 1996; 81 Alejandrino \& Valdés, 2006). One of the cases that illustrates the ambiguous situation of this group is the changing taxonomic status of the southwest Atlantic representatives classified as subspecies (Felimare picta lajensis) by Troncoso, García \& Urgorri (1998), as a valid species (Felimare lajensis) by Domínguez, García \& Troncoso (2006) and then downgraded again to a subspecific level by Dacosta, Padula \& Schrödl (2010). Similarly, Felimare tema, originally described from Ghana by Edmunds (1981) was reclassified as subspecies (Felimare picta tema) by Ortea, Valdés \& Garcia-Gomez (1996). Color pattern similarities between Felimare picta verdensis and F. picta tema (sensu Ortea, Valdés \& Garcia-Gomez, 1996) also raised some doubts on the validity of these subspecies. Table S1 in Supplementary Data summarizes the main taxonomic classifications and also the overlapping distribution areas of some of these subspecies.

The phylogenetic relationships of the $F$. picta complex with other taxa long recognised as distinct species, both from the east and west Atlantic, remains largely unknown. $F$. picta is the only amphi-Atlantic species of this genus, but along the east Atlantic shores and central Atlantic islands we can find several species with overlapping distributions. Along the west Atlantic shore this phylogenetic relationship is even more complex, with a close trans-isthmian phylogenetic relationship between all eastern Pacific and the Atlantic/Mediterranean Felimare species, together with two species previously assigned to the genus Mexichromis (F. porterae and $F$. kempfi) reported by Johnson \& Gosliner (2012).

\subsection{Biogeography}

The ability to cross biogeographic barriers is normally restricted to highly mobile species or species that produce propagules with high potential to disperse at least during a particular phase of their life-cycle (Briggs, 1974). Aside from landmasses, long extensions of deep oceanic water and abrupt changes of physical or chemical properties of marine water can effectively restrict the colonization potential of inshore organisms (Floeter et al., 2008; Luiz et al., 2011). Furthermore, the effectiveness of these permeable barriers may be influenced by the potential to establish new populations in the recently colonized habitats (Luiz et al., 2011).

The mid Atlantic barrier (MAB) is a deep ocean gap formed by the Atlantic Ocean basin in the last 85 Myr. It spans a long distance with a minimum straight-line distance of approximately 
$1112800 \mathrm{~km}$, therefore acting as a barrier to larval dispersal for marine organisms (Floeter et al., 112 2008; Luiz et al., 2011).

113 For molluscs, Vermeij (2005) concluded that 30.8\% (northeastern Atlantic) to 47.3\%

114 (northwestern Atlantic) of the North-Atlantic species present an amphi-Atlantic distribution.

115 However, F. picta is the Atlanto-Mediterranean Chromodorididae with the wider distribution 116 area (Ortea, Valdés \& García-Gómez, 1996) and one of the few present in both margins of the

117 Atlantic. the Mediterranean and most islands of the tropical and temperate north Atlantic, having 118 crossed major biogeographic barriers. With such an extensive geographical distribution, several 119 subspecies were historically assigned to F. picta. Some of these subspecies are morphologically 120 very similar and present overlapping geographical distributions (e.g. F. picta picta and F. picta 121 webbi cf. Ortea, Valdés \& García-Gómez, 1996). A molecular phylogeny of this group would 122 shed some light on the taxonomic status of $F$. picta subspecies and other closely related Atlanto123 Mediterranean Felimare species.

124 In the present study we intend to clarify the taxonomic status of F. picta and its relationships 125 with other congeneric species. Simultaneously we want to evaluate the validity of its previously 126 proposed subspecies that currently raise numerous identification problems to many taxonomists. 127 The molecular phylogeny will be the starting point to infer the biogeographic relationships 128 within a group of taxa that was able to cross the main Atlantic biogeographic barriers.

\section{Material and methods}

131 2.1. Sampling

132 The species sampled in the present study, the geographical origin of the samples and the 133 GenBank accession numbers are listed in Table S2 in the Supplementary Data. Specimens were 134 identified and portions of tissue were provided by a nudibranch taxonomist (Dr. Gonçalo Calado 135 - see Gaspar, Rodrigues \& Calado (2009); Coelho \& Calado (2010); Haber et al. (2010); Calado 136 \& Silva (2012); Cruz, Gaspar \& Calado (2012)). The same nudibranch taxonomist kindly 137 provided pictures of several Felimare species and F. picta subspecies (Supplementary Data). 138 Extracted DNA is available from ISPA laboratory collections. Voucher specimens of F. lajensis 139 are available from Museu de Zoologia da Universidade de São Paulo (MZSP97468). In an 140 attempt to detect possible intraspecific variability in this species, a total of 32 F. picta 141 representing samples from its entire geographical distribution area and either side of the MAB 
142 were analysed. Additional sampling included the Strait of Gibraltar and the Mauritanian cold

143 water barrier limiting dispersal in other marine species (e.g. the Strait of Gibraltar) (see 144 Patarnello, Volckaert \& Castilho, 2007). Samples belonging to 13 different Felimare species 145 were also collected. These represent aproximately half of the described species of the eastern 146 Pacific, Atlantic and Mediterranean (WoRMS, 2014), including some already available in 147 GenBank, which were used for comparative purposes to provide a broader phylogenetic 148 framework and access the overall genetic divergence within this genus.

2.2. DNA extraction, amplification and sequencing

DNA was extracted from tissue samples preserved in ethanol, using a proteinase K/SDS based protocol (Sambrook, Fritsch \& Maniatis, 1989). Primers used to amplify a fragment 461 bp long from the 16S mitochondrial rDNA (16Ssar 5' CGC CTG TTT ATC AAA AAC AT 3' and 16Sbr 5' CCG GTC TGA ACT CAG ATC ACG T 3'), and a fragment 554 bp long from the COI (LCO1490 5' GGT CAA CAA ATC ATA AAG ATA TTG G 3' and HCO2198 5' TAA ACT TCA GGG TGA CCA AAA AAT CA 3'), are described in Palumbi et al. (1996) and Folmer et al. (1994), respectively. The primers 28SC1(F) 5' ACC CGC TGA ATT TAA GCA T 3' and 28SD3(R) 5' GAC GAT CGA TTT GCA CGT CA 3' used by Mollaret et al. (1997), Vonnemann et al. (2005) and Klussmann-Kolb et al. (2008) were also used to attempt to amplify a fragment of the nuclear 28S rDNA in these species.

PCR conditions were conducted as follows: $2 \mathrm{~min} .95^{\circ} \mathrm{C}$ followed by 35 cycles of $\left[95^{\circ} \mathrm{C}(30\right.$ sec. $), 54^{\circ} \mathrm{C}(30 \mathrm{sec}$.$) and 72^{\circ} \mathrm{C}\left(60 \mathrm{sec}\right.$.)] for the $16 \mathrm{~S}$ fragment; $2 \mathrm{~min} .95^{\circ} \mathrm{C}$ followed by 35 cycles of $\left[95^{\circ} \mathrm{C}(45 \mathrm{sec}),. 50^{\circ} \mathrm{C}(45 \mathrm{sec}\right.$.$\left.) and 72^{\circ} \mathrm{C}(60 \mathrm{sec}).\right]$ for the $\mathrm{COI}$ fragment and $4 \mathrm{~min} .95^{\circ} \mathrm{C}$ followed by 38 cycles of $\left[94^{\circ} \mathrm{C}(30 \mathrm{sec}),. 52^{\circ} \mathrm{C}(50 \mathrm{sec}\right.$.$\left.) and 72^{\circ} \mathrm{C}(120 \mathrm{sec}).\right]$ followed by 10 $\min$. at $72^{\circ} \mathrm{C}$ for the $28 \mathrm{~S}$ fragment.

PCR products were purified using microClean (MicroZone, www.microzone.co.uk), and sequenced in STABVIDA (http://www.stabvida.net/) using these primers.

2.3. Phylogenetic analysis

170 Following Johnson (2011) we used an outgroup species from the Dendrodorididae family: 171 Doriopsilla pelseneeri d'Oliveira, 1895.. DNA sequences were analysed and edited using the 172 software program CodonCode aligner (v. 3.5, CodonCode Corporation) and were aligned 
173 separately using M-Coffee (Notredame, Higgins \& Heringa, 2000). Manual alignment masking 174 was performed, by excluding loci scored as 'bad' by M-Coffee, in order to improve sign-to-noise 175 ratio. Transitional saturation was examined by plotting transitions and transversions against 176 sequence divergence using GTR distance and implementing Xia et al. test (Xia et al., 2003; Xia $177 \&$ Lemey, 2009) test of substitution saturation available in Dambe v. 5.3.108 (Xia, 2013).

178 Each fragment and a concatenation of both fragments were analysed using four phylogenetic 179 inference methods: 1) maximum-parsimony (MP) with 100 heuristic searches using random 180 additions of sequences and implementing the TBR algorithm, as implemented in PAUP $4.0 \mathrm{~b} 10$ 181 (Swofford, 2001); 2) minimum-evolution (ME), also implemented in PAUP with 1000 182 resamplings, was implemented using the best-fit model of molecular evolution chosen according 183 the Bayesian Information Criterion as implemented in JModeltest 2.0 (Darriba et al., 2012); 3) 184 Maximum Likelihood, as implemented in RaxML (Stamatakis, Hoover \& Rougemont, 2008) and 185 4) Bayesian inference (BI) performed using MCMC as implemented in MrBayes v. 3.2 186 (Ronquist et al., 2012), with two independent runs of four Metropolis-coupled chains of four million generations each in order to estimate the posterior probability distribution. Topologies were sampled every 100 generations and a majority-rule consensus tree was estimated after discarding the first 10\% samples. Convergence was verified by inspecting the average standard deviation of split frequencies and tracing likelihood throughout samples in Tracer v1.6 (Drummond et al., 2012). Both ML and BI analyses of the concatenated alignment considered two partitions for which independent parameters were estimated. For the first three phylogenetic inference methods, branch support values for each node were tested by bootstrap analysis, with 100 resamplings (Felsenstein, 1985). Net between group mean distances were calculated using Mega (Tamura et al., 2013) using Tamura-Nei distance with gamma model estimated by the composite likelihood method.

\section{Results}

\subsection{Sequence analysis}

The null hypothesis of congruence between the two data sets (16S and COI rDNA) was not rejected $(P=0.33)$ by the ILD test (Farris et al., 1995). Therefore the results presented in subsequent sections relate to the analysis of the concatenation of the $16 \mathrm{~S}$ and COI rDNA

203 fragments. The combined sequence of the 16S + COI rDNA fragments resulted in an alignment 
204 of 1026 base pairs. Of these, 712 characters are constant, 66 variable characters are parsimony205 uninformative and 248 are parsimony-informative characters. No saturation was observed for the $20616 \mathrm{~S}$ and COI datasets or the concatenated fragment with both sequences $(P<0.001$ for all 207 combinations) (Xia et al., 2003; Xia \& Lemey 2009).

208 Minimum-evolution (ME), using the best-fit model of molecular evolution chosen according the 209 Bayesian Information Criterion as implemented in JModeltest 2.0 (Darriba et al., 2012) was $210 \mathrm{HKY}+\mathrm{I}+\mathrm{G}$ for $16 \mathrm{~S}$; $\operatorname{TrN}+\mathrm{I}+\mathrm{G}$ for $\mathrm{COI}$ and $\mathrm{TIM} 3+\mathrm{I}+\mathrm{G}$ for the concatenated $16 \mathrm{~S}$ and COI.

211 Since we were not able to amplify the COI fragment of $F$. acriba, known from the Caribbean, 212 this species is not shown in the concatenated tree with the $16 \mathrm{~S}$ and COI fragments (Figure 1). 213 However, all phylogenetic analysis with the 16S fragment recovered this species as the sister 214 species of $F$. bayeri with very high support values (Bayesian analysis with posterior probability 215 of 1.0 and maximum parsimony with bootstrap value of 100).

216 Estimated net evolutionary divergence between species and subspecies is presented in Table 1.

217 Genetic similarities and haplotypes shared between F. picta collected from Mexico to the 218 Mediterranean, including the Azores (F. picta picta, F picta webbi and F. picta azorica sensu 219 Ortea, Valdés \& García-Gómez, 1996) revealed no genetic isolation. The genetic distance 220 between these subspecies and the west African samples (0.255-0.272), which would be classified 221 as F. p. tema and F. p. verdensis (sensu Ortea, Valdés \& García-Gómez, 1996) is larger than the 222 distance shown for F. zebra (0.185) and is similar to the one shown for F. bayeri $(0.277)$.

\section{Phylogenetic analysis}

The genus Felimare and higher order relationships

The results presented in Figure 1A support the distinctiveness of the eastern Pacific, Atlantic and Mediterranean Felimare species compared to the Indo-Pacific Hypselodoris species. The Caribbean Felimare kempfi failed to be included in a distinct clade with the remaining species of this genus.

The Felimare picta complex

232 The monophyly of $F$. picta, including specimens from all geographical areas, is not supported 233 given the internal position of several west Atlantic species, such as $F$. zebra and F. lajensis 234 (Figure 1B). Although ME and BI recovered a third west Atlantic taxa, F. bayeri, as the sister 
235 species of the African subspecies of $F$. picta ( $F . p$. tema and $F$. p. verdensis), this phylogenetic 236 relationship was not supported by ML or MP methods. As a precautionary measure these 237 incongruent results were interpreted as an unresolved trichotomy (Figure 1B). Nevertheless, $F$. 238 bayeri was always recovered in a clade, including the remaining taxa of the $F$. picta complex, 239 with very high support values. These results alone show that F. picta, as currently defined, 240 constitutes a paraphyletic group.

The results presented in Figure 1B also confirm that, unlike other species of the same genus, the distribution range of $F$. picta encompasses both margins of the Atlantic Ocean together with several North Atlantic islands, namely the Azores. Interestingly, samples from this central Atlantic archipelago had identical or similar haplotypes compared to others from Mexico (west Atlantic), Portugal and Spain (east Atlantic) or Italy (Mediterranean).

The paraphyly of F. picta and, consequently, the phylogenetic relationships between its subspecies and other related taxa requires a revision of the taxonomic status of this complex of species and raises the question of how many transatlantic colonisation events could have occurred within the $F$. picta complex alone.

For identification purposes $F$. picta complex diagnostic nucleotide characteres are listed for $16 \mathrm{~S}$ and COI fragments in Table S3 in the Supplementary Data.

\section{Discussion}

256

Molecular phylogenetic relationships suggest that current taxonomy of the genus Felimare and, in particular, the $F$. picta subspecies should be revised. Currently, F. picta forms a paraphyletic group since $F$. lajensis, formerly classsified as $F$. picta lajensis, is the sister species of F. zebra, another west Atlantic Felimare species. West African $F$. tema, formerly described as an F. picta subspecies, should be reinstated as an independent species. $F$. picta, the only chomodorid with a distribution area encompassing both margins of the Atlantic Ocean, including the Archipelago of the Azores, and the Mediterranean Sea, includes

264 former $F$. picta picta, F picta webbi and F. picta azorica. No genetic structure was detected 
265 between these putative subspecies The taxonomic and biogeographic implications of these 266 proposals are addressed in the sections below.

\subsection{Taxonomic implications}

269

270

271

272

273

274

275

276

277

278

279

280

281

282

283

284

285

286

287

288

289

290

291

292

293

294

Although presenting a distinct color pattern when compared to other F. picta, the genetic data presented here suggests that the Azorean samples are not isolated from the west or east Atlantic and Mediterraneam samples. Although differences in phenotype may result from recent genetic divergence or distinct ecological influences, the classification of taxa into different species or subspecies should be accompanied by genetic studies that are able to demonstrate their monophyly. The results are compatible with two alternative hypotheses: (i) genetic isolation between $F$. picta subspecies was recent, requiring fast evolving genetic markers, such as microsatellites, to detect reproductive isolation or; (ii) at least some of these "subspecies" coexist and interbreed. Considering the paraphyly of the $F$. picta complex and the fact that Ortea, Valdés \& Garcia-Gomez (1996) did not describe valid morphological characters or designate type specimens to justify the nomination of several new subspecies (e.g. F. p. azorica), F. p. picta, F. p. webbi or F. p. azorica should, by order of precedence and for the time being, be synonymized under F. picta (Schultz, 1836) instead of assigning them to different subspecies. This is particularly important within the chromodorids, which are known to be quite diversified in terms of color patterns. In fact, some of the characters described for some subspecies, such as the absence of yellow lines in F. p. azorica, are also observed in F. p. picta and the lack of discriminating differences is even more evident between the latter and F. p. webbi.

F. p. tema (Edmunds, 1981) and F. p. verdensis (Ortea, Valdés \& García-Gómez, 1996) show no genetic differences between samples collected from Senegal and from Cape Verde. These results are not surprising since Ortea, Valdés \& García-Gómez (1996) reclassified F. tema, originally described by Edmunds (1981) from Ghana as a subspecies of F. picta, and described a new subspecies: F. p. verdensis, endemic to Cape Verde Islands, São Tomé and southern Angola. However, they did not designate any type specimens and the morphological variability described by Edmunds (1981) for F. tema is similar to that described for the specimens of F. p. tema and F. p. verdensis except for one difference related to radula secondary denticles which are absent in $F$. p. tema. These specimens are characterized by longitudinal orange lines, orange submarginal 
295 border, orange lined gills and a dark blue background color with lighter blue patches along the 296 submarginal mantle border.

297 The results presented here suggest that, for the time being, the original taxonomic classification 298 by Edmunds (1981) should be reinstated and F. tema should include both F. p. tema and F. p. 299 verdensis. In fact, this tropical eastern Atlantic species, whose distribution area would now 300 include Senegal, Ghana, south Angola and the archipelagoes of Cape Verde and São Tomé, is 301 more distantly related to other parapatric norheastern Atlantic F. picta than the allopatric western 302 Atlantic F. lajensis.

303

F. p. lajensis Troncoso, Garcia \& Urgorri, 1998 was originally described for Brazil as a subspecies of $F$. picta but has been re-assessed as a different species by Dominguéz et al. (2006). Its ambiguos taxonomic status (species or subspecies) is rooted on the morphological descriptions that: i) distinguish this taxon from remaining $F$. picta, based on the dark blue to violet body pattern with blue to violet gills, five spaced dorsal lines and a deferent duct with a narrow preprostatic portion (Troncoso, García \& Urgorri, 1998 and Domínguez, García \& Troncoso, 2006) or ii) suggest that it should be included in F. picta because some specimens have gill rachis with yellow lines, up to nine dorsal yellow lines and a yellow or white mantle margin (DaCosta, Padula \& Schrödl, 2010). In fact, F. picta present gill rachis with yellow lines, only three dorsal lines and the preprostatic portion of the deferent duct is absent. DaCosta, Padula \& Schrödl (2010) also showed that radular and allosperm receptacles differences described by Troncoso, García \& Urgorri (1998) and Domínguez, García \& Troncoso (2006) were not supported by the additional material analysed by those authors. Due to the wide morphological variation DaCosta, Padula \& Schrödl (2010) decided to keep this taxon as a subspecies of $F$. picta until detailed anatomical comparisons and also molecular approaches are concluded to better understand not only the satus of this taxon but also the relationships between all F. picta subspecies.

321 In our study $F$. picta samples from Brazil were always recovered in a clade with $F$. zebra 322 (Bermuda) and the genetic distance suggests a close relationship between these taxa. This southwestern Atlantic taxon is the sister clade to all remaining $F$. picta, excluding the east

324 tropical Atlantic $F$. tema which diverged near the base of the $F$. picta complex as did also $F$. 325 bayeri. 
327 Although our results using two mitochondrial markers are clear and unambiguous, phylogenies

328 based on mitochondrial DNA may result in misleading speciation histories when there are 329 discrepancies with nuclear DNA (e.g. Zhang and Hewitt, 1996; Shaw, 2002). Joint analysis of 330 mitochondrial and nuclear DNA may be informative even when results from both types of 331 fragments are contradictory, particularly "when the context for the conflict is understood" 332 (Rubinoff and Holland, 2005). In fact, nuclear phylogenies frequently reinforce mitochondrial 333 phylogenies (e.g. Levy et al. 2011). On the other hand, nuclear loci present several technical 334 limitations in phylogenetic inference such as low copy number, heterozygosity, paralogous loci 335 with multiple copies and low substitution rate, which make them uninformative when comparing 336 close related species or even subspecies (for a revision see Rubinoff \& Holland, 2005). One 337 example of this argument are the chromodorid species analysed by Ortigosa et al. (2014) where 338 nuclear markers did not add any additional information or resolve ambiguous results on closely 339 related Felimida species. Although, reclassifying F. picta, F. tema and F. lajensis as independent 340 species should be considered provisional until more specimens are throughly analysed and 341 nuclear markers are compared, the suggestions presented above clarify the taxonomy and help to 342 define groups that are monophyletic and well characterized with mitochondrial DNA markers 343 and morphological characters.

In a wider phylogenetic scope the results indicate a basal politomy with four branches. Western Atlantic F. ruthae and eastern Atlantic/west Mediterranean F. bilineata appear as individualized branches. A third clade includes the $F$. picta complex, with the amphi-Atlantic $F$. picta, western Atlantic F. lajensis, F. zebra and F. bayeri and eastern Atlantic F. tema and its sister species, the eastern Pacific F. californiensis. Future phylogenetic studies will show if other eastern Pacific species are included in the same or in different clades together with the remaining Atlantic and Mediterranean species. A forth clade includes the remaining eastern Atlantic and Mediterranean species: F. cantabrica, F. fontandraui, F. orsinii, F. midatlantica and F. villafranca. The exclusion of $F$. kempfi from the Felimare clade was already argued by Johnson \& Gosliner (2012) placing this Caribbean species with the eastern Pacific F. porterae as a potential sister group to a larger clade of eastern Pacific, Atlantic and Mediterranean Felimare species (Johnson \& Gosliner 2012). 
357 The fact that the Indo-Pacific species are included in a distinct monophyletic clade corroborates

358 the conclusions of Johnson \& Gosliner (2012) pointing to an ancient diversification of the

359 Felimare species in the eastern Pacific, Atlantic and Mediterranean since the closure of the

360 Tethys Sea in the East by the end of the Miocene.

361

362

4.2. Felimare picta complex biogeography

363 Sea surface currents and larvae characteristics, including larval behaviour, are crucial for an 364 organism to be able to cross important biogeographic barriers. Briggs (1995) described four 365 biogeographic provinces later reviewed by Spalding et al (2007) and Briggs \& Bowen (2012) 366 that are relevant to this study: northeastern Atlantic Lusitania (including Macaronesia and the 367 Mediterranean) (but see Almada et al., 2013), tropical West Africa, the Caribbean and Brazil. 368 These provinces are delimited by several soft (non-terrestrial) barriers such as: (1) the mid369 Atlantic barrier; (2) the Mauritanian cold water upwelling in the northwestern coast of Africa; (3)

370 the Orinoco/Amazonas freshwater plume; (4) the Almeria/Oran front separating the Atlantic 371 from the Mediterranean. Some organisms can cross these areas when environmental conditions 372 are favourable which result in the establishment of new populations or species (e.g. Floeter et al., 373 2008).

374 Based on the phylogenetic results presented in this study the success of the $F$. picta complex 375 crossing all these biogeographic barriers underlined by the amphi-Atlantic distribution of $F$. 376 picta is not reflected among the other chomodorids.

Panama Isthmus

379

380 The high diversity in the eastern Pacific and the opportunity to colonize the western Atlantic via 381 Panama Isthmus before its closing, contributed to a higher species richness in this area compared 382 to other Atlantic regions. This fact allowed not only for species to exist on both sides of the 383 isthmus, but also some taxa to radiate to many others (Lessios, 2008). Examples of sister 384 relationships across this particular vicariant event include opisthobranchs (e.g. Malaquias \& 385 Reid, 2009) and fish (Briggs, 1995; Muss et al., 2001; Grant et al., 2010). This pattern is also 386 observed between the eastern Pacific $F$. californiensis and the $F$. picta complex. In fact, the $F$. 387 picta complex is more closely related with $F$. californiensis than with other Atlanto- 
388 Mediterranean Felimare species which probably means that the origin of this species complex is 389 posterior to the closure of this hard (terrestrial) biogeographic barrier.

Mid-Atlantic Barrier

392 The Atlantic ocean barrier is an important constraint to the migration of individuals between both sides of the Atlantic (Briggs, 1995). However, crossing of the MAB by some species has been suggested by the amphiatlantic distribution of these species or because they have sister taxa on both margins of the Atlantic reflecting historical speciation events (Carmona et al., 2011). The genus Felimare and, in particular, the $F$. picta complex, illustrates both these patterns. Present geographic distribution of F. picta includes the west and eastern Atlantic Ocean and also the Mediterranean Sea which is supported by molecular data presented here. Although this hypothesis should be tested in the future with additional samples and appropriate phylogeographic analysis, the phylogeny of this group suggests that the mid-Atlantic barrier was probably crossed twice by this complex of species. First, an earlier colonization event resulted in the divergence of $F$. tema (including $F$. picta tema and $F$. picta verdensis) in equatorial Africa region. Second, a separation between the clade $F$. lajensis $F$. zebra and $F$. picta (including $F$. picta from western and northeastern Atlantic) and a transatlantic migration resulting in the colonization of both sides of the Atlantic by this later species. Major oceanic surface currents suggest that this migration could have followed a westward route, particularly in the equatorial region (e.g. Silva et al., 2014 and references therein). With predominant surface currents from northwest Africa to Central America (North equatorial current) and from southwest Africa to southeast South America (South equatorial current), one hypothesis to explain current species distribution would be an westward migration with speciation along the American coast. However this westward migration hypothesis is highly improbable if we consider the phylogeny of this group of species, particularly the basal position of the west Atlantic species within the F. picta complex phylogeny and the eastern Pacific $F$. californiensis being the sister species of this clade. An alternative hypothesis would be an eastward colonization from the western Atlantic to the European and African coasts which, if we assume that the present surface current pattern was already in effect, could follow two alternative routes: a northern route along the Gulf stream 418 followed by the Azores and the Canaries currents (Barton, 2001) and an equatorial route 
419 following the north equatorial countercurrent (see Fonseca et al., 2004). Phylogenetic patterns

420 showed in this work and those reported by other authors based on morphological and meristic

421 data (Gosliner \& Johnson, 1999 and Alejandrino \& Valdés 2006) also support this eastward

422 migration hypothesis.

423 Assuming that the origin of F. picta is posterior to the closure of the Isthmus of Panama and 424 therefore posterior to the settlement of the Gulf Stream, the similarity between Mexican samples 425 of $F$. picta and an individual collected in the Azores suggest that this archipelago may have 426 acted, and still acts, as a stepping-stone in this northern route. This hypothesis is further 427 supported by the fact that during glacial periods these currents were even stronger than in present 428 times (Wunsch, 2003) which could result in the rapid transportation from west to the east 429 Atlantic of planktotrophic larvae or adults and eggs on rafting materials. The equatorial counter 430 current is seasonal, being stronger during the Spring (Richardson et al., 1992), when it reaches 431 surface transport velocities between $23 \mathrm{~cm} \mathrm{~s}^{-1}$ (Richardson et al., 1992) and $45 \mathrm{~cm} \mathrm{~s}^{-1}$ (Urbano, 432 Almeida \& Nobre, 2008). This would mean that the mid Atlantic barrier could be crossed at 433 maximum velocity in less than 10 days $\left(38.88 \mathrm{Km} \mathrm{day}^{-1}\right)$. This would allow an independent 434 eastward migration by a southern route which could have led to the origin of $F$. tema in the 435 tropical west African coast. Only future phylogeographic studies with population samples of $F$. 436 picta from both sides of the Atlantic may shed some light on the dispersion route of this species.

Mauritanian cold water barrier

439 The present allopatric distribution of $F$. tema and $F$. picta could be explained by the persistence 440 of biogeographic barriers and/or by ecological constraints. The cold water barrier along the Mauritanian shores due to strong upwelling (Marañón et al., 2001) and the Pleistocenic glaciations could have prevented F. tema from colonizing the northeastern Atlantic shores. More recently, with the settling of F. picta in the northeastern Atlantic shores other ecological constraints may have been in effect. This argument is based on the fact that F. tema is deeply rooted within a clade with several west Atlantic extant species and $F$. picta shares a common ancestor with $F$. lajensis and F. zebra, which are also west Atlantic species. If the hypothesis of the "eastward migration" proves to be correct, present allopatric distribution of $F$. tema and $F$. picta may be the result of two independent dispersion processes: the first resulting in the 
449 speciation of the tropical east Atlantic F. tema from an west Atlantic ancestor, and the second

450 resulting in the colonization of the northeastern Atlantic and the Mediterranean by F. picta.

451 Examples of this eastward migration are common across a large array of taxonomic groups and 452 are much more common than migrations on the opposite directions (Ávila, 2005; Rocha et al., 453 2008; Beldade et al., 2009). This may be the result of the predominant current patterns described 454 above and the higher species richness in the west Atlantic shores.

455

Orinoco/Amazonas Barrier

457 Genetic isolation between central western and southwestern Atlantic may have occurred about 6 million years with the origin of the Amazon River (Nunan, 1992; Hoorn 1994). Variation in salinity levels due to river fresh water plumes and the absence of appropriate hard substrate along the southwest Atlantic coast became known as the Central American Gap and represent an important biogeographic barrier for marine organisms (Rocha, 2003; Ludt \& Rocha 2014). Since the closure of the Isthmus of Panamá the patterns of epipelagic circulation remained approximately constant (Haug \& Tiedemann, 1998) therefore, conditions were appropriate for this biogeographic semi-permeable barrier to promote a recent split between $F$. lajensis and $F$. zebra.

The question still remains however on why among all chromodorids has the F. picta complex experienced such a success crossing all main Atlantic biogeographic barriers? Even considering $F$. picta sensu strictu, this is the only chromodorid whose distribution encompasses northwestern Atlantic, northeastern Atlantic and the Mediterranean. Futhermore, nudibranchs and the chromodorids, in particular, are sedentary and have a dispersion ability that is much reduced during all life stages. Rafting on floating materials could explain their ability to colonize distant locations, however the individuals of these species are benthic and are usually found over sponges upon which they feed. Therefore it is improbable that these organisms may disperse during their adult phase. Coelho \& Calado (2010) repported that $F$. picta shows the largest egg size and planktotrophic larvae length at hatching reported among nudibranch molluscs (for a review see Todd, Lambert \& Davies, 2001). Although $F$. villafranca have even larger eggs, it presents direct and not planktotrophic development. It is commonly accepted that large larvae have higher survival rates during transport in the water column. Although, Shulman \& 
480 Bermingham (1995) found no relationship between oceanographic patterns, larval duration and 481 population genetic structuring in the Caribbean, they refer that a different scenario could emerge 482 on larger geographic scales. For this purpose, additional studies on different species which were 483 also able to cross the MAB, such as the Chromodorididae Tyrinna evelinae and Cadlina rumia, 484 from a sister group of the Chromodorididae (Johnson, 2011), could be of extreme interest as well 485 as tagging mark and recapture of these species to determine if the distance they travel enables 486 physical crossing.

487 From a molecular ecology perspective, genetic assignment tests could indicate if the most likely 488 sources of recruits are from local or distant populations (see Piry et al., 2004; Wilson \& Rannala, 489 2003).

490 A comprehensive study of the phylogeny of the genus Felimare, including all its species and 491 nuclear DNA markers is still needed to clarify the taxonomy of this group. Furthermore, 492 phylogeographic data would provide information on the direction and number of colonization 493 events of each taxonomic entity and would allow the implementation of species delimitation 494 analysis (see Puillandre et al., 2012).

495 Nevertheless the biogeographic considerations and phylogenetic relationships described above may help to refine current information on a group of marine organisms that have been raising the attention of a broad community from evolutionary biology and ecology to natural products chemistry.

\section{Acknowledgements}

We would like to thank the help of Dr. Gonçalo Calado for all the expertise identifying nudibranchs specimens, for the pictures of several specimens and valuable comments on the manuscript. We would like to thank Rita Coelho and the Portuguese Institute of Malacology for the pictures of several specimens. We would also like to thank the Museu de Zoologia da Universidade de São Paulo for samples under the material transfer agreement No. 003/2007/MZUSP with the Portuguese Institute of Malacology.

\section{References}


509 Alejandrino A, Valdés A. 2006. Phylogeny and biogeography of the Atlantic and Eastern Pacific 510 Hypselodoris stimpson, 1855 (Nudibranchia, Chromodorididae) with the description of a new 511 species from the Caribbean Sea. Journal of Molluscan Studies 72:189-198.

512 Almada VC, Toledo JF, Brito A, Levy A, Floeter S, Robalo JI, Martins J, Almada F. 2013. 513 Biogeography of the Lusitanian Province and the distinctiveness of the temperate coastal 514 ichthyofauna in the northeastern Atlantic. Frontiers of Biogeography 5:20-28.

515 Ávila SP. 2005. Processos e padrões de dispersão e colonização nos Rissoidae 516 (Mollusca:Gastropoda) dos Açores. Ph.D. Thesis, University of Açores, Portugal, Ponta 517 Delgada.

518 Barton E. 2001. Canary and Portugal currents. In: Steele JH, Thorpe SA, Turekian KK, Eds. 519 Ocean currents. London, Academic Press.

520 Beldade R, Heiser JB, Robertson DR, Gasparini JL, Floeter SR, Bernardi G. 2009. Historical 521 biogeography and speciation in the Creole wrasses (Labridae, Clepticus). Marine Biology 522 156:679-687.

523 Briggs JC. 1974. Operation of zoogeographic barriers. Systematic Zoology 23:248-256.

524 Briggs JC. 1995. Global Biogeography - Developments in Palaeontology and Stratigraphy. 525 Amsterdam, Elsevier.

526 Briggs JC, Bowen BW. 2012. A realignment of marine biogeographic provinces with particular 527 reference to fish distributions. Journal of Biogeography 39:12-30.

528 Calado G, Silva JP. 2012. Lesmas do Mar do Algarve. Guia de Moluscos Opistobrânquios da 529 Costa Sul de Portugal. Faro: Edições Subnauta (ISBN: 978-989-96406-2-7).

530 Carmona L, Malaquias M, Gosliner T, Pola M, CerveraJL. 2011. Amphi-Atlantic distributions 531 and cryptic species in Sacoglossan sea slugs. Journal of Molluscan Studies 77:401-412.

532 Coelho R, Calado G. 2010. Spawn and early development of NE Atlantic species of 533 Hypselodoris (Gastropoda: Opisthobranchia). Iberus 28:63-72.

534 Cruz JF, Gaspar H, Calado G. 2012. Turning the game around: toxicity in a nudibranch-sponge 535 predator-prey association. Chemoecology 22:47-53. 
536 Dacosta S, Padula V, Schrödl M. 2010. A new species of Hypselodoris and a redescription of 537 Hypselodoris picta lajensis (Nudibranchia: Chromodorididae) from Brazil. The Veliger 51:1553825.

539 Darriba D, Taboada GL, Doallo R, Posada D. 2012. jModelTest 2: more models, new heuristics 540 and parallel computing. Nature Methods 9:772.

541 Domínguez M, García FJ, Troncoso J. 2006. Some aspects of the family Chromodorididae 542 (Opisthobranchia: Nudibranchia) from Brazil, with description of a new species. Scientia Marina $543 \quad 70: 621-634$.

544 Drummond AJ, Suchard MA, Xie D, Rambaut A. 2012. Bayesian phylogenetics with BEAUti 545 and the BEAST 1.7. Molecular Biology and Evolution 29:1969-1973.

546 Edmunds M. 1981. Opisthobranchiate Mollusca from Ghana: Chromodorididae. Zoological 547 Journal of the Linnean Society 72: 175-201.

548 Farris JS, Källersjö M, Kluge AG, Bult C. 1995. Testing significance of incongruence. 549 Cladistics 10:315-319.

550 Felsenstein J. 1985. Confidence-Limits on Phylogenies - an Approach Using the Bootstrap. 551 Evolution 39:783-791.

552 Floeter SR, Rocha LA, Robertson DR, Joyeux JC, SmithVaniz WF, Wirtz P, Edwards AJ, 553 Barreiros JP, Ferreira CEL, Gasparini JL, Brito A, Falcón JM, Bowen BW, Bernardi G. 2008. 554 Atlantic reef fish biogeography and evolution. Journal of Biogeography 35:22-47.

555 Folmer O, Black M, Heah W, Lutz R, Vrijenhoek R. 1994. DNA primers for amplification of 556 mitochondrial cytochrome C oxidase subunit I from diverse metazoan invertebrates. Molecular 557 Marine Biology and Biotechnology 3:294-299.

558 Fonseca CA, Goni GJ, Johns WE, Campos EJD. 2004. Investigation of the North Brazil Current 559 retroflection and North Equatorial Countercurrent variability. Geophysical Research Letters $560 \quad 31: 1-5$.

561 Gaspar H, Rodrigues AI, Calado G. 2009. Comparative study of chemical defences from two 562 allopatric north atlantic subspecies of Hypselodoris picta (Mollusca: Opisthobranchia). Açoreana $5636: 137-143$. 
564 Gosliner TM, Johnson RF. 1999. Phylogeny of Hypselodoris (Nudibranchia: Chromodorididae)

565 with a review of the monophyletic clade of Indo-Pacific species, including descriptions of twelve 566 new species. Zoological Journal of the Linnean Society 125:1-114.

567 Grant WS, Lecomte F, Bowen BW. 2010. Biogeographical contingency and the evolution of 568 tropical anchovies (genus Cetengraulis) from temperate anchovies (genus Engraulis). Journal of 569 Biogeography 37:1352-1362.

570 Haber M, Cerfeda S, Carbone M, Calado G, Gaspar H, Neves R, Maharajan V, Cimino G, 571 Gavagnin M, Ghiselin MT, Mollo E. 2010. Coloration and defense in the nudibranch gastropod 572 Hypselodoris fontandraui. The Biological Bulletin 218:181-188.

573 Haug GH, Tiedemann R. 1998. Effect of the formation of the Isthmus of Panama on Atlantic 574 Ocean thermohaline circulation. Nature 393: 673-676.

575 Hoorn C. 1994. An environmental reconstruction of the palaeo-Amazon River system (middle to 576 late Miocene, NW Amazonia). Palaeogeography Palaeoclimatology Palaeoecology 112: 187577238.

578 Johnson RF. 2011. Breaking family ties: taxon sampling and molecular phylogeny of 579 chromodorid nudibranchs (Mollusca, Gastropoda). Zoologica Scripta 40:137-157.

Johnson RF, Gosliner TM. 2012. Traditional taxonomic groupings mask evolutionary history: a molecular phylogeny and new classification of the chromodorid nudibranchs. PLoS ONE 7: 582 e33479.

Klussmann-Kolb A, Dinapoli A, Kuhn K, Streit B and Albrecht C. 2008. From sea to land and beyond - New insights into the evolution of euthyneuran Gastropoda (Mollusca). BMC Evolutionary Biology 8:57.

Lessios HA. 2008. The Great American Schism: Divergence of Marine Organisms after the Rise of the Central American Isthmus. Annual Review of Ecology, Evolution and Systematics 39: 6358891.

589 Levy A, Wirtz P, Floeter SR, Almada VC. 2011. The Lusitania Province as a center of 590 diversification: the phylogeny of the genus Microlipophrys (Pisces: Blenniidae). Molecular 591 Phylogenetics and Evolution 58:409-413. 
592 Ludt WB, Rocha LA. 2014. Shifting seas: the impacts of Pleistocene sea-level fluctuations on the

593 evolution of tropical marine taxa. Journal of Biogeography 42:25-38.

594 Luiz OJ, Madin JS, Robertson DR, Rocha LA, Wirtz P, Floeter SR. 2011. Ecological traits 595 influencing range expansion across large oceanic dispersal barriers: insights from tropical 596 Atlantic reef fishes. Proceedings of the Royal Society B: Biological Sciences 279:1033-40.

597 Malaquias MAE, Reid DG. 2009. Tethyan vicariance, relictualism and speciation: evidence from 598 a global molecular phylogeny of the opisthobranch genus Bulla. Journal of Biogeography $59936: 1760-1777$.

600 Marañón E, Holligan PM, Barciela R, González N, Mouriño B, Pazó MJ, Varela M. 2001. 601 Patterns of phytoplankton size structure and productivity in contrasting open-ocean 602 environments. Marine Ecology Progress Series 216:43-56.

603 Mollaret I, Jamieson BGM, Adlard RD, Hugall A, Lecointre G, Chombard C, Justine JL. 1997. 604 Phylogenetic analysis of the Monogenea and their relationships with Digenea and Eucestoda 605 inferred from 28SrDNA sequences. Molecular and Biochemical Parasitology 90:433-438.

606 Muss A, Robertson DR, Stepien CA, Wirtz P, Bowen BW. 2001. Phylogeography of 607 Ophioblennius: the role of ocean currents and geography in reef fish evolution. Evolution $608 \quad 55: 561-572$.

609 Notredame C, Higgins DG, Heringa J. 2000. T-Coffee: A novel method for fast and accurate 610 multiple sequence alignment. Journal of Molecular Biology 302:205-17.

611 Nunan G. 1992. Composition, species distribution, and zoogeographical affinities of the 612 Brazilian reef fish fauna. Ph.D. Thesis, University of Newcastle upon Tyne, U.K.

613 Ortea J, Valdés A, García-Gómez JC. 1996. Revisión de las especies atlánticas de la familia 614 Chromodorididae (Mollusca: Nudibranchia) de grupo cromático azul. [Review of the Atlantic 615 species of the family Chromodorididae (Mollusca: Nudibranchia) of the blue chromatic group.] 616 Avicennia 1:1-165.

617 Ortigosa D, Pola M, Carmona L, Padula V, Schrodl M, Cervera JL. 2014. Redescription of 618 Felimida elegantula (Philippi, 1844) and a preliminary phylogeny of the european species of 619 Felimida (Cromodorididae). Journal of Molluscan Studies 80:541-550. 
620 Ortigosa D, Valdés A. 2012. A new species of Felimare (formerly Mexichromis) (Gastropoda: 621 Opisthobranchia: Chromodorididae) from the Yucatan Peninsula, Mexico. The Nautilus 126: 98622104.

623 Palumbi S, Martin A, Romano S, McMillan WO, Stice L, Grabowski G. 1996. The Simple Fool's 624 Guide to PCR, Version 2.0. Department of Zoology and Kewalo Marine Laboratory, University 625 of Hawaii.

626 Patarnello T, Volckaert FA, Castilho R. 2007. Pillars of Hercules: is the Atlantic-Mediterranean 627 transition a phylogeographical break? Molecular ecology 16: 4426-4444.

628 Piry S, Alapetite A, Cornuet JM, Paetkau D, Baudouin L, Estoup A. 2004. GENECLASS2: A 629 Software for Genetic Assignment and First-Generation Migrant Detection. Journal of Heredety $630 \quad 95: 536-539$.

631 Puillandre N, Lambert A, Brouillet S, Achaz G. 2012. ABGD, Automatic Barcode Gap 632 Discovery for primary species delimitation. Molecular Ecology 21:1864-1877.

633 Richardson PL, Arnault S, Garzoli S, Bruce JG. 1992. Annual cycle of the Atlantic North 634 Equatorial Countercurrent. Deep-Sea Research 39:997-1014.

635 Rocha LA. 2003. Patterns of distribution and processes of speciation in Brazilian reef fishes. 636 Journal of Biogeography 30:1161-1171.

637 Rocha LA, Rocha CR, Robertson DR, Bowen BW. 2008. Comparative phylogeography of 638 Atlantic reef fishes indicates both origin and accumulation of diversity in the Caribbean. $B M C$ 639 Evolutionary Biology 8:157.

640 Ronquist F, Teslenko M, van der Mark P, Ayres DL, Darling A, Höhna S, Larget B, Liu L, 641 Suchard MA, Huelsenbeck JP. 2012. MrBayes 3.2: efficient Bayesian phylogenetic inference 642 and model choice across a large model space. Systematic Biology 61:539-42.

643 Rubinoff D, Holland BS. 2005. Between Two Extremes: Mitochondrial DNA is neither the 644 Panacea nor the Nemesis of Phylogenetic and Taxonomic Inference. Systematic Biology 54: $645952-961$.

646 Rudman WB. 1984. The Chromodorididae (Opisthobranchia: Mollusca) of the Indo-West 647 Pacific: a review of the genera. Zoological Journal of the Linnean Society 81:115-273. 
648 Sambrook J, Fritsch EF, Maniatis T. 1989. Molecular cloning: A laboratory manual. Cold 649 Spring Harbor Press. New York.

650 Silva G, Horne JB, Castilho R. 2014. Anchovies go north and west without losing diversity: 651 Post-glacial range expansions in a small pelagic fish. Journal of Biogeography 41:1171-1182.

652 Shaw KL. 2002. Conflict between nuclear and mitochondrial DNA phylogenies of a recent 653 species radiation: What mtDNA reveals and conceals about modes of speciation in Hawaiian 654 crickets. Proceedings of the National Academy of Sciences 99:16122-16127.

655 Shulman MJ, Bermingham E. 1995. Early life histories, ocean currents, and the population 656 genetics of Caribbean reef fishes. Evolution 49:897-910.

657 Spalding MD, Fox HE, Gerald GR, Davidson N, Ferdaña ZA, Finlayson M, Halpern BS, Jorge 658 MA, Lombana AL, Lourie SA, Martin KD, Mcmanus E, Molnar J, Recchia CA, Robertson J. 659 2007. Marine ecoregions of the world: A bioregionalization of coastal and shelf areas. 660 BioScience 57:573-583.

661 Stamatakis A, Hoover P, Rougemont J. 2008. A Fast Bootstrapping Algorithm for the RAxML 662 Web-Servers. Systematic Biology 57:758-771.

663 Swofford, DL. 2001. PAUP*. Phylogenetic Analysis Using Parsimony (*and Other Methods) v 664 4.0b10. 4b.10 ed. Sinauer Associates, Sunderland, Massachusetts.

665 Tamura K, Nei M, Kumar S. 2004. Prospects for inferring very large phylogenies by using the 666 neighbor-joining method. Proceedings of the National Academy of Sciences 101:11030-11035.

667 Tamura K, Stecher G, Peterson D, Filipski A, Kumar S. 2013. MEGA6: Molecular Evolutionary 668 Genetics Analysis version 6.0. Molecular Biology and Evolution 30:2725-2729.

669 Todd CD, Lambert WJ, Davies J. 2001. Some perspectives on the biology and ecology of 670 nudibranch molluscs: generalisations and variations on the theme that prove the rule. Bollettino 671 Malacologico 37:105-120.

672 Troncoso JS, Garcia FJ, Urgorri V. 1998. Anatomical data on rare Hypselodoris picta (Schultz, 673 1836) (Gastropoda, Doridacea) from the coast of Brazil with description of a new subspecies. 674 Bulletin of Marine Science 63:133-141. 
675 Turner LM, Wilson NG. 2007. Polyphyly across oceans: a molecular phylogeny of the 676 Chromodorididae (Mollusca, Nudibranchia). Zoologica Scripta 37:23-42.

677 Urbano DF, Almeida RAF, Nobre P. 2008. Equatorial Undercurrent and North Equatorial 678 Countercurrent at $38^{\circ} \mathrm{W}$ : A new perspective from direct velocity data. Journal of Geophysical 679 Research, 113:C04041.

680 Vermeij GJ. 2005. From Europe to America: Pliocene to Recent trans-Atlantic expansion of 681 cold-water North Atlantic molluscs. Proceedings of the Royal Society B 272: 2545-2550.

682 Vonnemann V, Schrödl M, Klussmann-Kolb A, Wägele H. 2005. Reconstruction of the 683 phylogeny of the Opisthobranchia (Mollusca: Gastropoda) by means of 18s and 28s rRNA gene 684 sequences. Journal of Molluscan Studies 71:113-125.

685 Willan RC, Coleman N. 1984. Nudibranchs of Australasia. Australasian Marine Photographic 686 Index, Caringbah, Sydney.

687 Wilson GA, Rannala B. 2003. Bayesian inference of recent migration rates using multilocus 688 genotypes. Genetics 163:1177-1191.

689 Wollscheid-Lengeling E, Boore J, Brown W, Wägele H. 2001. The phylogeny of Nudibranchia 690 (Opisthobranchia, Gastropoda,Mollusca) reconstructed by three molecular markers. Organisms 691 Diversity and Evolution 1:241-256. Wollscheid E, Wägele H. 1999. Initial results on the 692 molecular phylogeny of the Nudibranchia (Gastropoda, Opisthobranchia) based on 18S rDNA 693 data. Molecular Phylogenetics and Evolution 13:215-226.

694 WoRMS Editorial Board. 2014. World Register of Marine Species. Available from 695 http://www.marinespecies.org at VLIZ. Accessed 2014-10-06

696 Wunsch C. 2003. Determining paleoceanographic circulations, with emphasis on the Last Glacial 697 Maximum. Quaternary Science Reviews 22:371-385.

698 Xia X. 2013. DAMBE5: A comprehensive software package for data analysis in molecular 699 biology and evolution. Molecular Biology and Evolution 30:1720-1728.

700 Xia X, Lemey P. 2009. Assessing substitution saturation with DAMBE. Pp. 615-630 in P. 701 Lemey, M. Salemi, and A.-M. Vandamme Eds. The Phylogenetic Handbook: A Practical 702 Approach to DNA and Protein Phylogeny. Cambridge University Press, UK, Cambridge. 
703 Xia X, Xie Z, Salemi M, Chen L, Wang Y. 2003. An index of substitution saturation and its 704 application. Molecular Phylogenetics and Evolution 26:1-7.

705 Zhang D, Hewitt GM. 1996. Nuclear integrations: challenges for mitochondrial DNA markers.

706 Trends in Ecology and Evolution 11:247-251.

707 


\section{1}

Phylogenetic relationships of the Atlanto-Mediterranean "F. picta complex" and other related species.

(A) Phylogenetic relationships between several Indo-West Pacific Hypselodoris species and eastern Pacific, Atlantic and Mediterranean Felimare species obtained from the 16S+COI molecular data. Bayesian posterior probabilities (BI) and MP, ME and ML bootstrap support are shown above and below each node, respectively. (B) Phylogenetic relationships of the Atlanto-Mediterranean "F. picta complex". 
(A)

Doriopsilla pelseneeri NE Atlantic

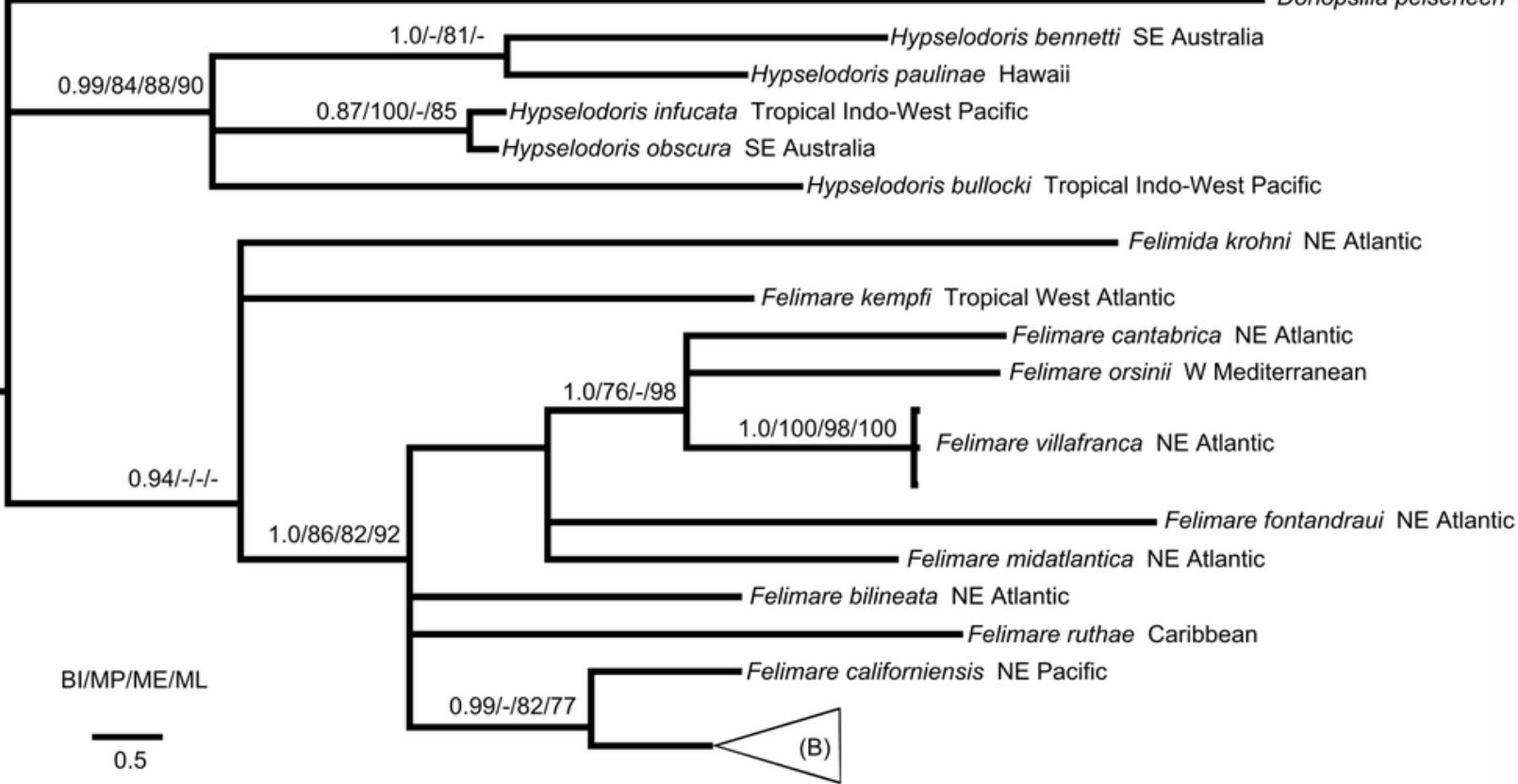

(B)

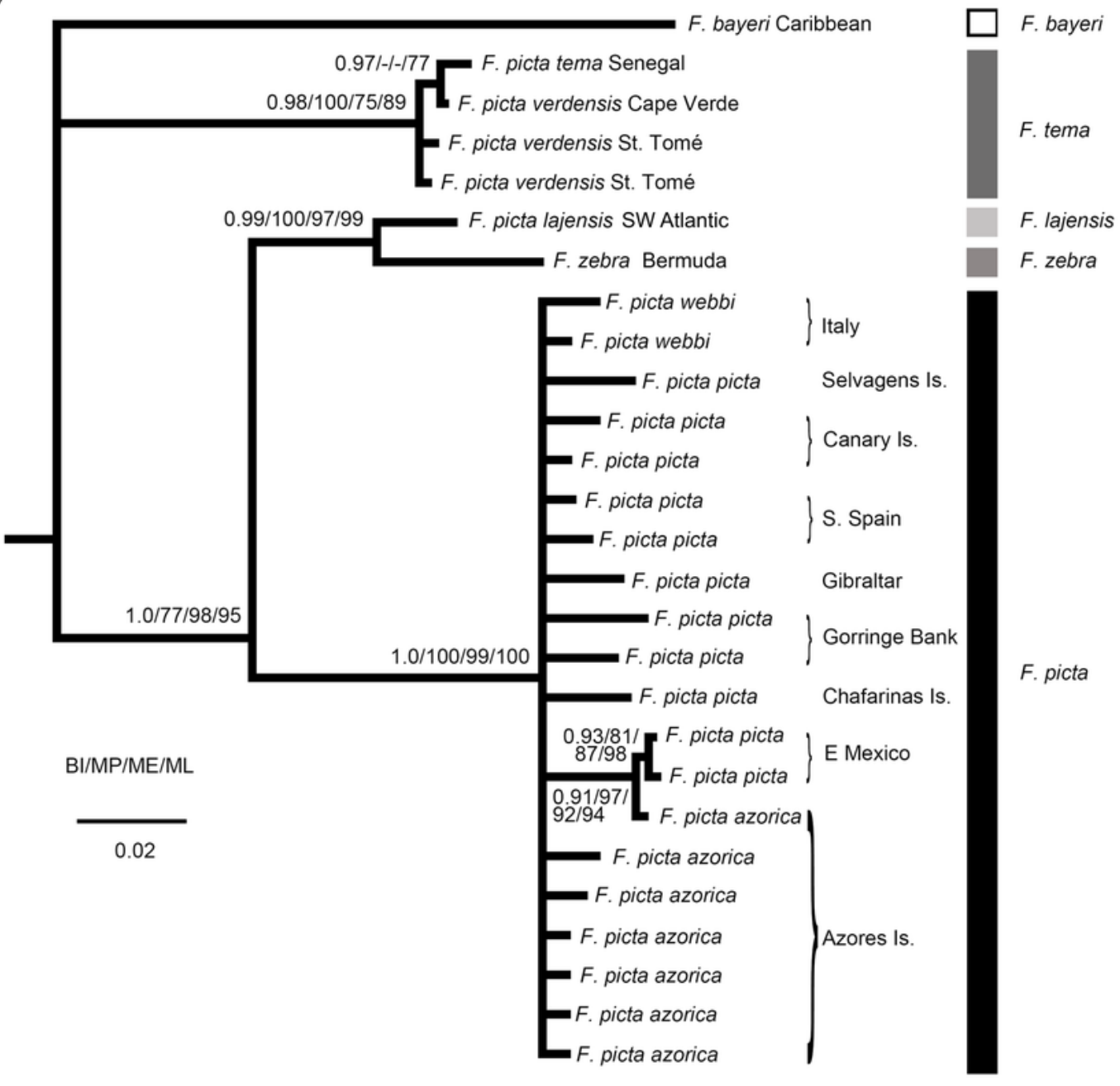




\section{Table $\mathbf{1}$ (on next page)}

Estimates of net evolutionary divergence

Table 1 - Estimates of net evolutionary divergence between groups of sequences from $F$. picta subspecies, other Atlanto-Mediterranean Felimare species and Indo-West Pacific Hypselodoris species. The number of base substitutions per site from estimation of net average between groups of sequences are shown. Standard error estimate(s) are shown above the diagonal. The Felimare picta complex is highlighted in bold. Analyses were conducted using the Maximum Composite Likelihood model (Tamura, Nei \& Kumar, 2004). The rate variation among sites was modeled with a gamma distribution (shape parameter = 0.426). The analysis involved 45 mtDNA sequences and all ambiguous positions were removed resulting in a total of 1124 nucleotides in the final dataset. Evolutionary analyses were conducted in MEGA6 (Tamura et al., 2013). 


\begin{tabular}{|c|c|c|c|c|c|c|c|c|c|c|c|c|c|c|c|c|c|c|c|}
\hline & Chromodoris & $\begin{array}{c}F . \\
\text { bayeri }\end{array}$ & $\begin{array}{c}F . \\
\text { bilineata }\end{array}$ & $\begin{array}{c}F . \\
\text { californensis }\end{array}$ & $\begin{array}{c}F . \\
\text { cantabrica }\end{array}$ & $\begin{array}{c}F . \\
\text { fontadraui }\end{array}$ & $\begin{array}{c}F . \\
\text { kempfi }\end{array}$ & $\begin{array}{c}F . \\
\text { lajensis }\end{array}$ & $\begin{array}{c}F . \\
\text { midatlantica }\end{array}$ & $\begin{array}{c}F . \\
\text { orsinii }\end{array}$ & $\begin{array}{l}\text { F. picta } \\
\text { azorica }\end{array}$ & $\begin{array}{c}\text { F. picta } \\
\text { picta }\end{array}$ & $\begin{array}{c}\text { F. picta } \\
\text { webbi }\end{array}$ & $\begin{array}{c}\text { F. picta } \\
\text { tema }\end{array}$ & $\begin{array}{c}\text { F. picta } \\
\text { verdensis }\end{array}$ & $\begin{array}{c}F . \\
\text { ruthae }\end{array}$ & $\begin{array}{c}F . \\
\text { villafranca }\end{array}$ & $\begin{array}{c}F . \\
\text { zebra }\end{array}$ & Hypsel \\
\hline Chromodoris & & 0,546 & 0,617 & 0,613 & 0,735 & 0,631 & 0,496 & 0,628 & 0,560 & 0,624 & 0,690 & 0,702 & 0,691 & $\mathbf{0 , 5 6 5}$ & 0,560 & 0,872 & 0,576 & 0,591 & 0 \\
\hline F. bayeri & 1,766 & & 0,284 & 0,218 & 0,470 & 0,395 & 0,489 & 0,079 & 0,307 & 0,389 & 0,082 & 0,084 & $\mathbf{0 , 0 8 3}$ & 0,067 & 0,063 & 0,582 & 0,370 & 0,082 & 0 , \\
\hline F. bilineata & 2,055 & 0,922 & & 0,250 & 0,464 & 0,379 & 0,561 & 0,288 & 0,286 & 0,371 & 0,289 & 0,290 & 0,273 & 0,278 & 0,269 & 0,502 & 0,420 & 0,300 & 0,6 \\
\hline F. californensis & 2,069 & 0,692 & 0,771 & & 0,442 & 0,363 & 0,648 & 0,199 & 0,330 & 0,382 & $\mathbf{0 , 1 9 7}$ & $\mathbf{0 , 1 9 7}$ & 0,192 & 0,182 & 0,179 & 0,630 & 0,363 & 0,209 & 0,7 \\
\hline F. cantabrica & 2,592 & 1,536 & 1,520 & 1,454 & & 0,478 & 0,786 & 0,449 & 0,461 & 0,405 & 0,422 & 0,432 & 0,427 & 0,444 & 0,429 & 0,747 & 0,280 & 0,494 & 0,9 \\
\hline F. fontadraui & 2,095 & 1,260 & 1,227 & 1,162 & 1,596 & & 0,633 & 0,453 & 0,309 & 0,329 & 0,481 & 0,479 & 0,480 & 0,395 & 0,381 & 0,602 & 0,399 & 0,441 & 0,7 \\
\hline F. kempfi & 1,660 & 1,611 & 1,865 & 2,211 & 2,752 & 2,217 & & 0,519 & 0,586 & 0,653 & $\mathbf{0 , 5 7 6}$ & $\mathbf{0 , 5 7 7}$ & $\mathbf{0 , 5 7 2}$ & $\mathbf{0 , 5 3 3}$ & 0,522 & 0,845 & 0,679 & 0,542 & 0,7 \\
\hline F. lajensis & 2,138 & 0,258 & 0,930 & 0,644 & 1,485 & 1,499 & 1,749 & & 0,338 & 0,458 & 0,050 & $\mathbf{0 , 0 5 0}$ & $\mathbf{0 , 0 5 0}$ & $\mathbf{0 , 0 7 4}$ & 0,074 & 0,652 & 0,346 & 0,022 & 0,7 \\
\hline F. midatlantica & 1,839 & 0,941 & 0,919 & 1,053 & 1,497 & 0,968 & 1,973 & 1,085 & & 0,356 & 0,362 & 0,365 & $\mathbf{0 , 3 7 0}$ & 0,316 & 0,320 & 0,614 & 0,270 & 0,373 & 0,6 \\
\hline F. orsinii & 2,044 & 1,194 & 1,175 & 1,206 & 1,373 & 1,059 & 2,208 & 1,489 & 1,147 & & 0,487 & 0,490 & 0,484 & 0,381 & 0,386 & 0,627 & 0,206 & 0,440 & 0,6 \\
\hline F. picta azorica & 2,340 & 0,272 & 0,944 & 0,627 & 1,364 & 1,572 & 1,966 & 0,163 & 1,130 & 1,579 & & $\mathbf{0 , 0 0 0}$ & 0,000 & 0,081 & 0,078 & 0,651 & 0,408 & 0,054 & 0,7 \\
\hline F. picta picta & 2,379 & 0,277 & 0,949 & 0,628 & 1,405 & 1,564 & 1,973 & 0,165 & 1,138 & 1,591 & $\mathbf{0 , 0 0 0}$ & & $\mathbf{0 , 0 0 0}$ & $\mathbf{0 , 0 8 3}$ & 0,080 & 0,647 & 0,412 & 0,053 & 0,7 \\
\hline F. picta webbi & 2,338 & 0,272 & 0,891 & 0,617 & 1,387 & 1,569 & 1,957 & 0,164 & 1,155 & 1,569 & 0,000 & $\mathbf{0 , 0 0 0}$ & & 0,084 & 0,080 & 0,636 & 0,404 & 0,055 & 0,7 \\
\hline F. picta tema & 1,847 & 0,211 & $\mathbf{0 , 8 8 5}$ & $\mathbf{0 , 5 7 2}$ & 1,450 & 1,259 & 1,798 & 0,246 & 0,994 & 1,180 & 0,262 & 0,269 & 0,272 & & 0,004 & 0,614 & 0,404 & 0,089 & $0, \mathrm{C}$ \\
\hline F. picta verdensis & 1,826 & 0,200 & 0,866 & 0,570 & 1,406 & 1,207 & 1,767 & 0,250 & 1,019 & 1,218 & 0,255 & 0,259 & 0,260 & 0,008 & & $\mathbf{0 , 6 0 0}$ & 0,397 & 0,090 & $\mathbf{0}$, \\
\hline F. ruthae & 3,040 & 1,936 & 1,691 & 2,161 & 2,538 & 2,027 & 2,945 & 2,218 & 2,051 & 2,156 & 2,212 & 2,206 & 2,161 & 2,090 & 2,035 & & 0,620 & 0,614 & 0,8 \\
\hline F. villafranca & 1,920 & 1,128 & 1,313 & 1,124 & 0,901 & 1,274 & 2,339 & 1,068 & 0,830 & 0,635 & 1,269 & 1,283 & 1,256 & 1,263 & 1,247 & 2,112 & & 0,362 & 0, \\
\hline F. zebra & 1,942 & 0,258 & 0,943 & 0,650 & 1,617 & 1,441 & 1,841 & 0,072 & 1,192 & 1,388 & 0,181 & $\mathbf{0 , 1 7 9}$ & 0,185 & 0,281 & 0,287 & 2,045 & 1,100 & & 0 \\
\hline Hypselodoris & 2,209 & 2,135 & 2,113 & 2,736 & 3,266 & 2,459 & 2,473 & 2,693 & 2,350 & 2,401 & 2,585 & $\mathbf{2 , 5 7 7}$ & 2,484 & 2,423 & 2,424 & 2,978 & 2,182 & 2,463 & \\
\hline
\end{tabular}

